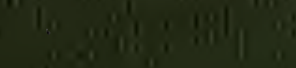


Digitized by the Internet Archive in 2010 with funding from Boston Public Library 
Please do not destroy or throw away this publication. If you have no further use for it write to the Geological Survey at Washington and ask for a frank to return it

\section{DEPARTMENT OF THE INTERIOR}

HUBERT WORK, Secretary

\section{United States Geological Survey George OTIS SMith, Director}

\section{Bulletin 760-A}

\section{PEDESTAL ROCKS IN THE ARID SOUTHWEST}

BY

KIRK BRYAN

Contributions to the geography of the United States, 1923

(Pages 1-11)

Published December 15, 1923

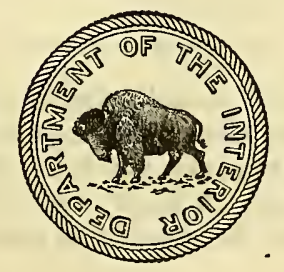

WASHINGTUN

GOVERNMENT PRINTING OFFICE.

: 


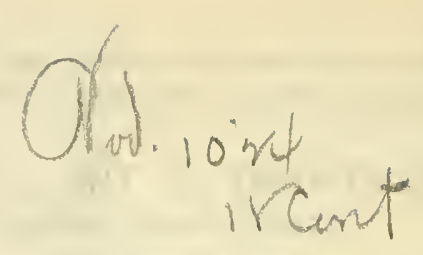

CONTENTS.

Page.

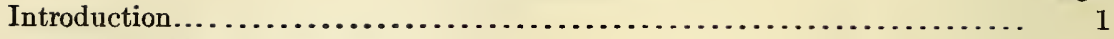

Pedestal rocks near Lees Ferry, Ariz . . . . . . . . . . . . . . . . . . . . . 2

General relations............................................. 2

Formation of the pedestal rocks............................ 3

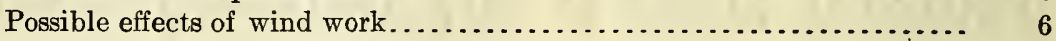

Pedestal rocks in southern Arizona............................... 7

Rocks of the pedestal type in central New Mexico................... 10

Conclusion.............................................. 11

\section{ILLUSTRATIONS.}

Plate I. A, Vermilion and Shinarump cliffs from Lees Ferry, Ariz.; $B$, Pedestal rock........................................

Page.

II. $A$, Pedestal rock; $B$, Block of conglomerate with vertical bedding

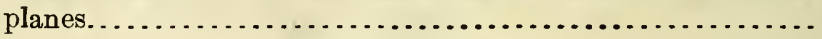

III. $A$, Conical hillock of Moenkopi formation near Lees Ferry, Ariz.; $B$, Incipient pedestal rock showing exfoliation..............

IV. $A$, Drip furrow below pedestal rock; $B$, Stains on under side of

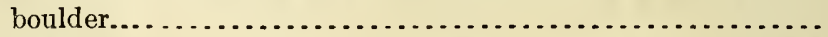

V. $A$, Pedestal rock of granite; $B$, Pedestal rocks and boulders of erosion.

NOTE.-The Geological Survey's annual volumes entitled "Contributions to the geography of the United States" are issued in parts, and the last part will include a volume title-page, table of contents, and index for the use of those who may wish to bind the separate parts. A small edition of the bound volume will also be issued, but copies can not be supplied to those who have received all the parts.

II 


\title{
CONTRIBUTIONS TO THE GEOGRAPHY OF THE UNITED STATES, 1923.
}

\author{
PEDESTAL ROCKS IN THE ARID SOUTHWEST.
}

\section{By Kirk Bryan.}

\section{INTRODUCTION.}

The relative effect of wind and water in the production of the characteristic and usually picturesque scenery of arid regions is still a moot question. Various criteria that have been put forward as indicating wind erosion are of uncertain value. For instance, pedestal rocks occurring in arid regions are cited as proof of wind erosion, though it has long been known that such rocks are also produced by differential weathering in humid regions. ${ }^{1}$ The citation in a French textbook ${ }^{2}$ of the Devil's Table, on the limestone escarpment above the Meuse near St. Mihiel, France, as an example of wind erosion seems quite certainly erroneous and may serve as an example of the length to which faulty interpretation has been carried.

General statements that pedestal rocks, also called "hoodoo rocks," "table rocks," "mushrooms," and "stone babies," are formed by the sand blast have been published by a number of authors." Gregory $^{4}$ states that

With the production of some of the "mushrooms," or "rock babies," to use the Navajo term, the wind is chiefly concerned; in the making of others the wind has assisted; many of them have attained this shape without the aid of the sand blast.

${ }^{1}$ Hughes, T. M., On some perched blocks and associated phenomena; Geol. Soc. London Quart. Jour., vol. 43, pp. 522-539, 1886. See alsə Alden, W. C., The Quaternary geology of southeastern Wisconsin: U. S. Geol. Survey Prof. Paper 106, p. 41, pl. 16, A, 1918. Hopkins, T. C., Marbles and other limestones: Arkansas Geol. Survey Ann. Rept., vol. 4, p. 343, pI. 17, 1890. Wynne, A. B., Notes on some physical features of the land formed by denudation: Royal Geol. Soc. Ireland Jour., vol. 1, p. 258, 1867.

2 Faideau, F., and Robin, A., Géologie élémentaire, les phénomènes actuels, p. 8, Paris, 1902.

${ }^{8}$ Walther, Johannes, Das Gesetz der Wüstenbildung, 2d ed., pp. 175-177, Leipzig, Quelle \& Meyer, 1912.

Endlich, F. M., On some striking products of erosion in Colorado: U. S. Geol. and Geog. Survey Terr. Bull. 4, pp. 831-864, 1878. The views expressed in this paper are very moderate.

Streeruwitz, W. H. von, Trans-Pecos Texas: Texas Geol. Survey Fourth Ann. Rept., for 1892, p. 145, 1893.

La Touche, T. D., Geology of western Rajputana: India Geol. Survey Mem., 35, p. 11, pl. 1, fig. 2, 1902.

Hill, R. T., Growth and decay of the Mexican Plateau: Eng. and Min. Jour., vol. 85, p. 688, 1908.

Blackwelder, Eliot, Cenozoic history of the Laramie region, Wyo.: Jour. Geology, vol. 17, p. 443, 1909.

Woodward, H. P., A geological reconnaissance of a portion of the Murchison gold field: Western Australia Geol. Survey Bull. 57, pp. 31-32, figs. 20, 21, 22, 1914 .

Hume, W. F., The physiography of arid lands (as illustrated by Desert Egypt), Geol. Mag., new. ser. dec. 6, vol. 1, p. 422, 1914 .

Hobbs, W. H., The erosional and degradatlonal processes of deserts, with special reference to the origin of desert depressions: Assoc. Am. Geog. Annals, vol. 3, p. 35, 1917.

${ }^{4}$ Gregory, H. E., Geology of the Navajo country-a reconnaissance of parts of Arizona, New Mexico, and Utah: U. S. Geol. Survey Prof. Paper 93, p. 138, 1917. 
In the present paper observations made in 1921 in northern Arizona and central New Mexico are recorded, and those made during the same and previous years in southern Arizona are introduced for comparison. Near Lees Ferry, in northern Arizona, an arid region, where wind work is notable in certain areas, the method of formation of some pedestal rocks by rain wash and differential erosion was determined with considerable precision. 'The conclusion reached is in accord with that of Gregory that even in an arid region the mere presence of pedestal rocks can not be cited as evidence of wind erosion. Definite proof must be brought forward not only that the marks of wind scour are present on the rocks but that this process has been the dominant one in the production of these peculiar forms.

\section{PEDESTAL ROCKS NEAR LEES FERRY, ARIZ.}

\section{GENERAL RELATIONS.}

Lees Ferry, on Colorado River, 132 miles north of Flagstaff, Ariz., has an elevation of 3,100 feet and a climate warmer and drier than most of the surrounding region. The available weather records indicate that the average rainfall in the region up to an altitude of 4,000 feet is probably less than 6 inches. $^{5}$

Lees Ferry is in the angle between the north-south Echo Cliffs and the east-west Vermilion Cliffs. The geology has been described by a number of authors. ${ }^{6}$ Only the relations of the Shinarump conglomerate, 40 feet thick, and the underlying Moenkopi formation, a gypseous red sandy shale about 500 feet thick, concern the subject of this paper, for the pedestal rocks are formed of blocks of Shinarump conglomerate resting on the Moenkopi formation. The blocks lie at the base of the Shinarump cliffs, secondary cliffs at the foot of the great cliffs formed by the massive sandstones of Jurassic age (Navajo and Wingate). For 13 miles west from Lees Ferry at the base of the Vermilion Cliffs and for 10 miles south from the ferry at the base of Echo Cliffs the Shinarump cliffs are well developed. Great blocks of the Shinarump conglomerate are undermined by the erosion of the Moenkopi and fall to the foot of the cliffs. ${ }^{7}$ The erosion of the Moenkopi is effected in part by rain wash but largely by temporary

\footnotetext{
5 For compiled weather records see Gregory, H. E., The Navajo country-a geographic and hydrographic reconnaissance of parts of Arizona, New Mexico, and Utah: U.S. Geol. Survey Water-Supply Paper 380, pp. 49-68, 1916.

${ }_{6}^{6}$ Howell, E. E., U. S. Geog. and Geol. Surveys W. 100th Mer. Rept., vol. 3, pp. 265-297, 1875. Gilbert, G. K., idem, pp. 63-85, pl. 11.

Dutton, C. E., Tertiary history of the Grand Canyon district: U. S. Geol. Survey Mon. 2, p. 205, 1882.

Davis, W. M., An excursion to the Grand Canyon of the Colorado: Harvard Coll. Mus. Comp. Zool. Bull., vol. 38, pp. 108-199, 1901; vol. 42, pp. 1-40, 1903.

Gregory, H. E., op. cit. (Prof. Paper 93), pp. 114-115, 135-136.

For a geologic map, see Bryan, Kirk, Discussion of "Tentative plan for the construction of a 780-foot rock-fill dam on Colorado River at Lees Ferry," by E. C. LaRue: Am. Soc. Civil Eng. Trans., vol. 86, pp. $228,240-1923$.

7 Davis, W. M., op. cit., p. 134, pl. 2.
} 
streams that cascade over the edge of the conglomerate and form deep vertical or nearly vertical channels in the shale. At favorable places also ground water seeps through the Moenkopi, as at Bitter Spring and a seep at Soap Creek. Because of the large content of gypsum and other soluble salts in the Moenkopi, this ground water is doubtless effective in undermining and sapping the cliffs. The principal erosive work in the area is accomplished by the ordinary weathering processes due to rain and streams, though there is some wind work, as described below.

\section{FORMATION OF THE PEDESTAL ROCKS.}

Blocks of conglomerate obviously derived from the cliffs not uncommonly stand on pedestals of Moenkopi shale (Pls. I, B; II, $A$; III, $B ; \mathrm{IV}, A$ and $B$ ). These rocks were noted by Gilbert, whose explanation is discussed in a later paragraph, and are mentioned by Davis.

It is noticeable that in all the pedestal rocks the bedding planes of the conglomerate blocks are horizontal, or nearly so. Blocks that lie with the bedding planes in a vertical position rest on cones of shale veneered with pebbles derived from the weathering of the conglomerate (Pl. II, $B$ ). There are present also conical hillocks veneered with similar pebbles apparently derived from blocks that have long since been destroyed by weathering (Pl. III, $A$ ). The conclusion seems to be obvious that when a block of conglomerate comes to rest with the bedding planes in a vertical position weathering loosens the cement rather rapidly, freeing the original pebbles. If, however, the bedding planes are nearly or quite horizontal the cement is resistant to weathering, brown crusts form on the surface, and the rock breaks up thereafter largely by exfoliation (Pl. III, $B$ ).

About 3 miles southwest of Lees Ferry, on a bench about 400 feet above the river and at the foot of the Vermilion Cliffs, north of the Marble Canyon, is a remarkable group of pedestal rocks. Here on the afternoon of July 14, 1921, there was a hard shower of an hour's duration during which it was possible to observe the effect of rain on pedestal rocks.

During the first 15 minutes of the shower the wind was easterly, and under both the large rocks (Pls. I, $B$, and II, $A$ ) it was dry even for a man seated on horseback. At the end of that time water began to drip from the east side of the blocks, and then, the wind shifting to the west, a heavy drip began on that side, though without stopping that on the east side. The water formed a film that extended from the overhang about 3 feet onto the under side of the rock. From this place a curtain of falling drops, or "drip curtain," 8 extended all

\footnotetext{
8 "Drip curtain" is a useful term to defime the somewhat discontinuous sheet of drops and threads of water that falls from any overhanging rock. It is strictly analogous to the sheet of water that falls from the eares of a house.
} 
around the pedestal. As the rain continued the film of water crept farther down the underside of the block until finally it reached and began to wet the top of the pedestal. These conditions were observed at both the large rocks (Pls. I, $B$, and II, $A$ ) and, with modifications, on numerous smaller and less perfect pedestal rocks.

The drip curtain forms on large blocks about 3 feet inside the outer limit of the block, though this distance is modified by the direction of the wind, the form of the block, and the texture of the rock. Under some rocks generally and under others locally the drip curtain is well defined and constant in position, but drops fall inside the main curtain at certain places, and secondary curtains may form. Where the drops strike the ground all the fine particles of earth are churned into mud and carried off in suspension by little rivulets; the coarser pieces, either fragments of thin sandstone from the Moenkopi or rounded pebbles from the Shinarump, remain and form a pavement that resists the action of the falling drops. The removal of fine material, however, forms a slight depression or "drip furrow" around the pedestal similar to that formed by the drip from the eaves of a house (Pl. IV, A). Little rivulets fed by rain water falling on the adjacent ground take advantage of these drip furrows and either deepen them or fill them with material brought from other places, which later may be removed by the drip. Under the larger rocks the drip furrow is not generally a continuous annular depression but forms part of the channels of these near-by rivulets.

The film of water that creeps over the surface of the rock feeds the drip curtain and then goes beyond it, finally reaching the top of the pedestal. If the rain should last long enough the film of water doubtless would cover the pedestal. During the shower in which these observations were made all the water that reached the top of the pedestal was absorbed there in a layer of loose material or soil 3 to 4 inches thick. Thence it doubtless penetrated into the shale below. Compared to the total amount of water that falls on the top and sides of the block during such a rain the amount that reaches the top of the pedestal is very small, but it has a definite effect in assisting in the weathering of the pedestal and in carrying away the products of weathering.

The action of rain in the formation of these pedestal rocks seems clear. The greater part of the water shed from the block falls in a drip curtain about 3 feet inside the periphery, forming a drip furrow from which temporary rivulets carry away the finer material. Rain wash from adjacent areas tends to concentrate in these furrows and assists in the process of transportation. Larger fragments doubtless lie in the pavement for a long time until they weather into particles of transportable size or until some larger stream by lateral planation moves into the area and carries them away. But durable fragments 


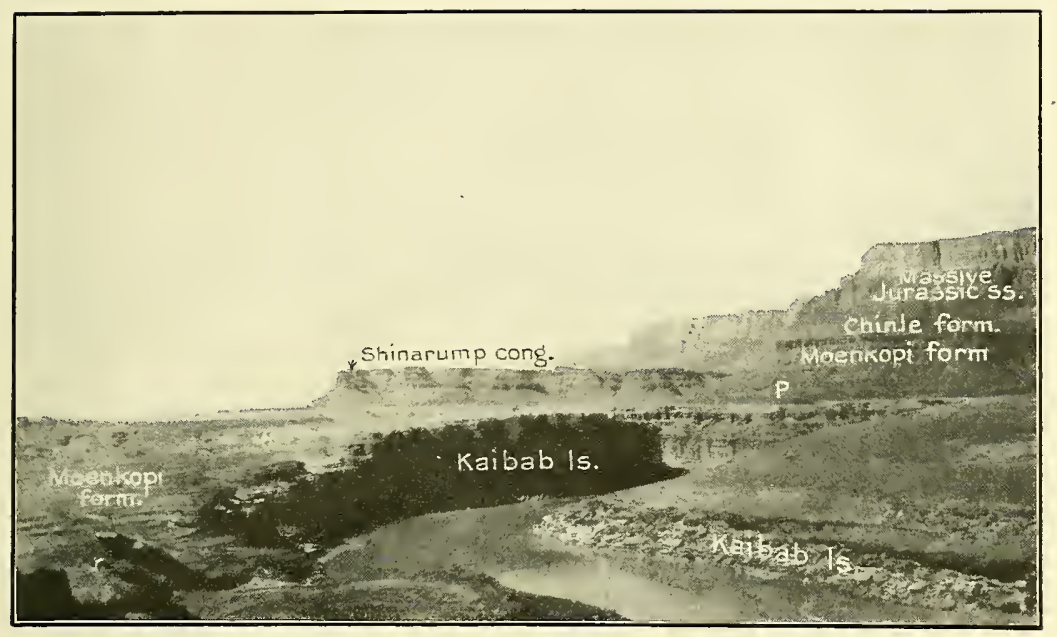

\section{A. VERMILION CLIFFS FROM LEES FERRY.}

View down Colorado River at head of Marble Canyon. Platform of Kaibab limestone is surmounted by the Shinarump cliffs, and these in turn by the great Vermilion Cliffs.' Pedestal rocks of Plates I, $A$, and II, $B$, at the locality marked P.

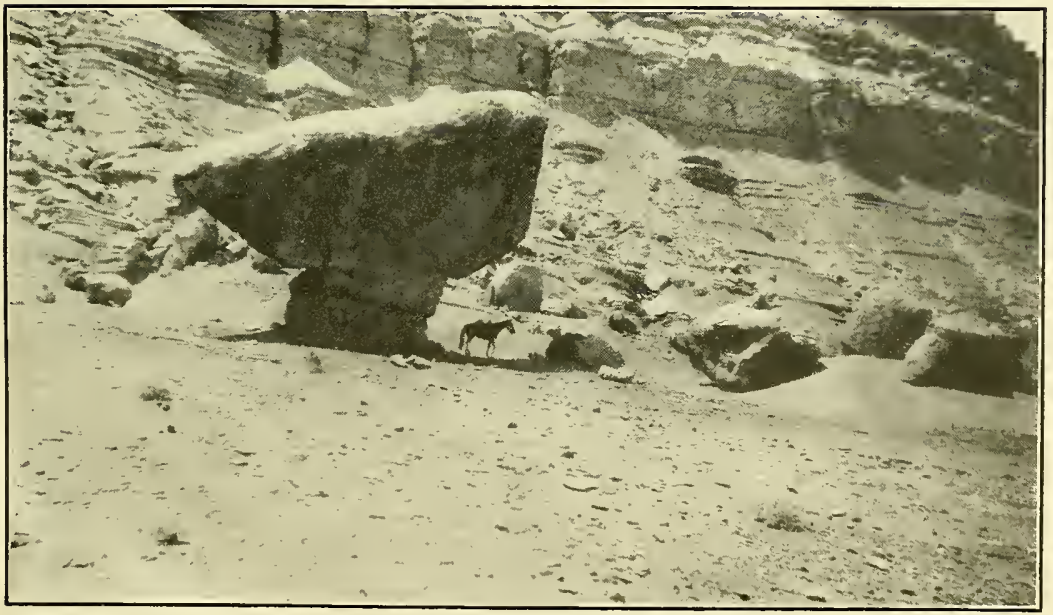

\section{B. PEDESTAL ROCK.}

Block of Shinarump conglomerate on a pedestal of Moenkopi shale. Note the details of erosion in the cliff of Moenkopi formation in the background, the abrupt break in slope to the pediment developed on similar material in the foreground, and the small number of blocks at the foot of the cliff. The block of the pedestal rock is marked with stains from the film of water which covers it in whole or in part during rains. 


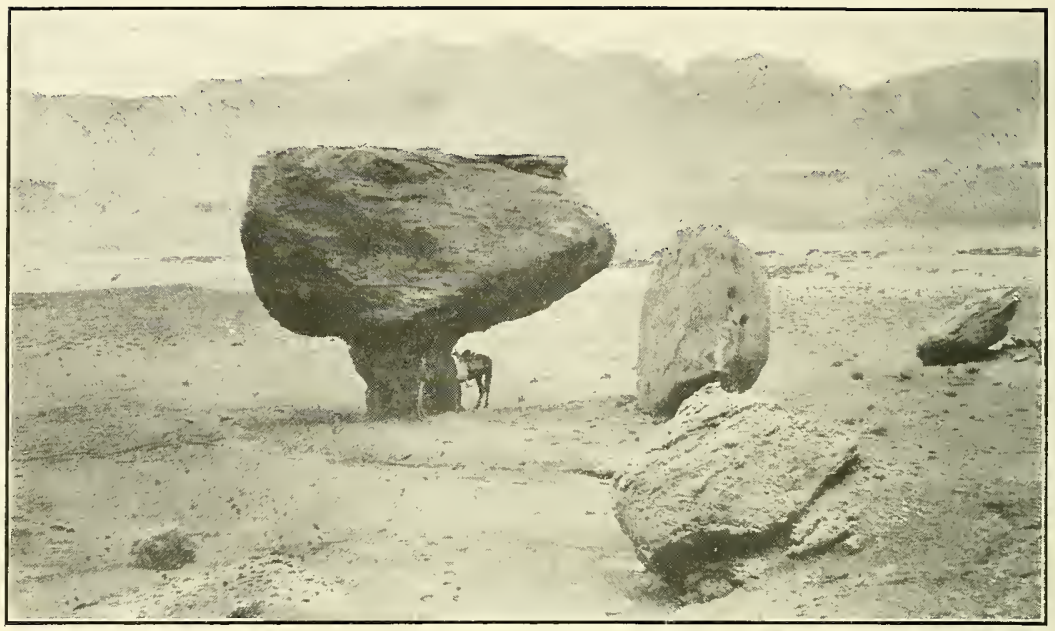

A. PEDESTAL ROCK.

Block of Shinarump conglomerate resting on a pedestal of Moenkopi shale. Note sloping plain (pediment), developed on Moenkopi formation, with a stream channel in foreground, Marble Canyon cut through the Kaibab limestone in the middle ground, and Echo Clifis in the background.

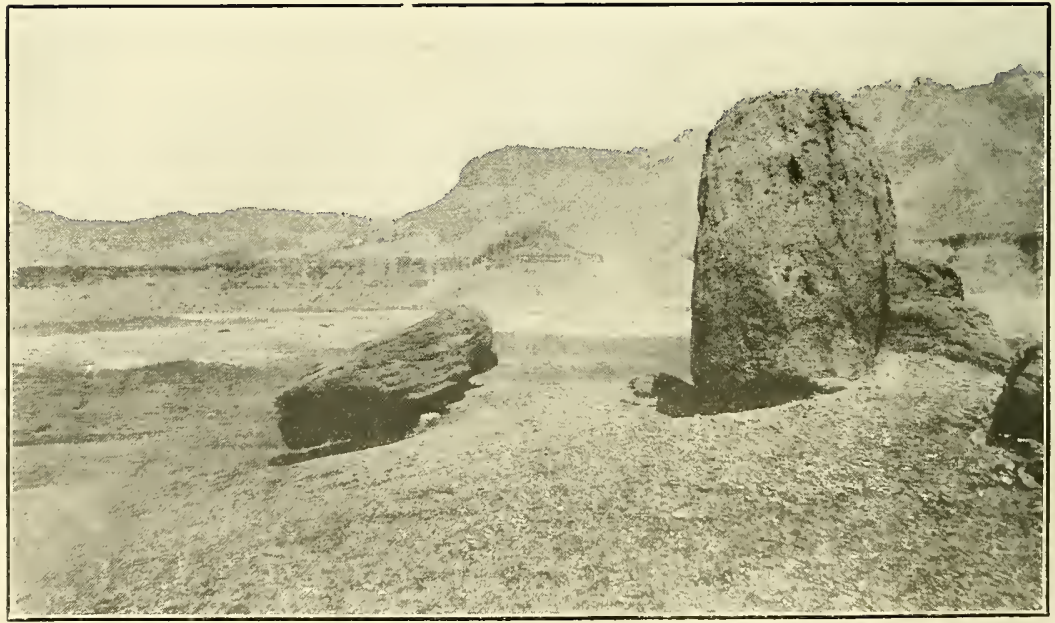

\section{B. BLOCK OF SHHNARUMP CONGLOMERATE WITH VERTICAL BEDDING PLANES.}

Rests on subconical hillock of Moenkopi formation veneered by gravel resulting from the disintegration of the block. The slight hollow on the lef $t$ of the block is due to incomplete protection from drip by the gravel. Marble Canyon is concealed in the light-colored area (Kaibab limestone) in the middle ground. Echo Cliffs with fret of Shinarump cliffs at the base rise in the background. 


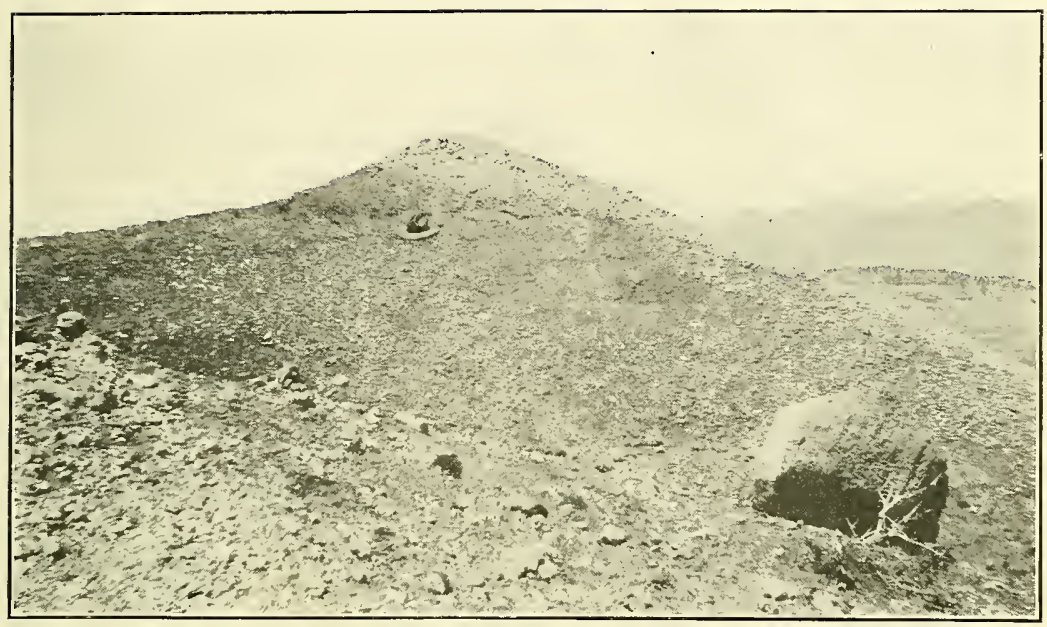

A. CONICAL HILLOCK OF MOENKOPI FORMATION NEAR LEES FERRY,

The Moenkopi formation here is a sandy shale, covered with gravel resulting from the disintegration of a block of Shinarump conglomerate.

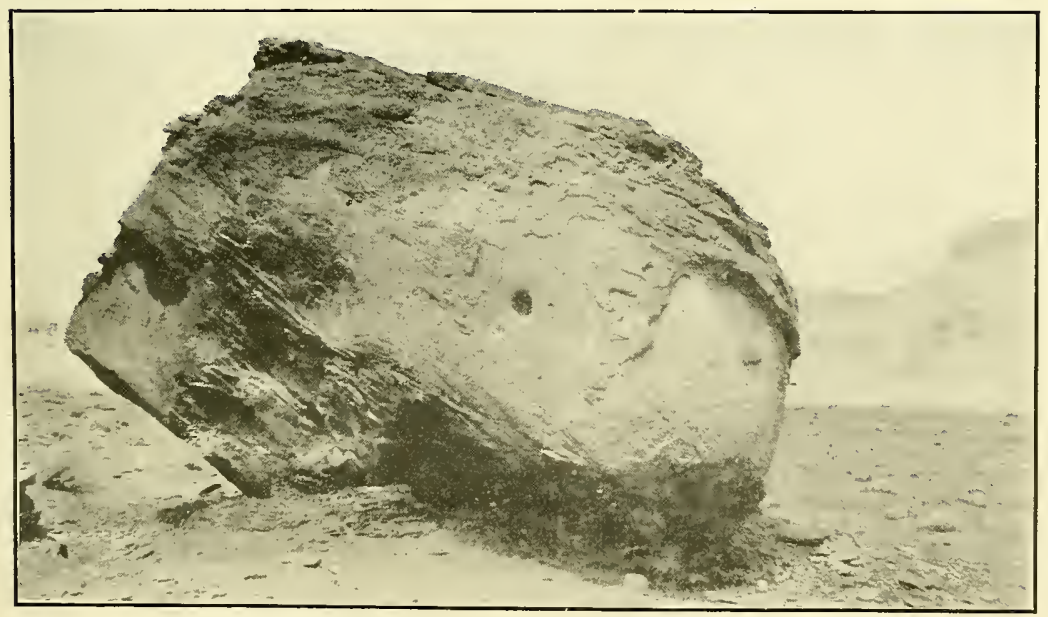

$B$. INCIPIENT PEDESTAL ROCK SIOWING EXFOLIATION.

Shows also cross-bedding of the Shinarump, irregular crusted surface, and a small pit due to solution of cement. 


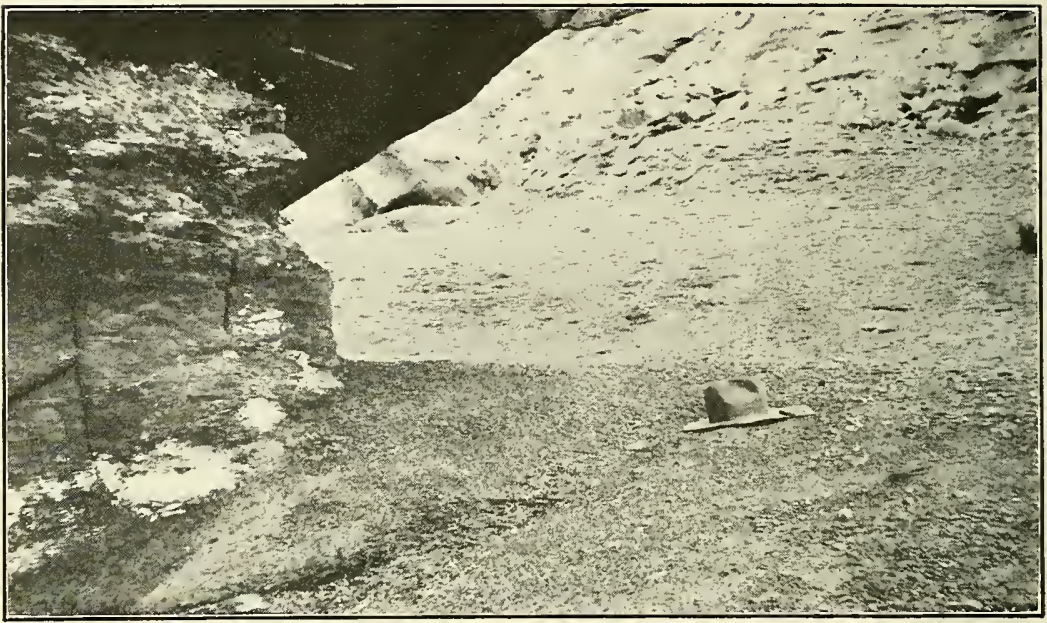

\section{A. DRIP FURROW BELOW PEDESTAL ROCK.}

Surface of the ground covered with scales of sandstone from the Moenkopi formation. The pedestal has vertical joint cracks widened by solution of veins of gypsum and is marked by white patches of salts derived from its interior.

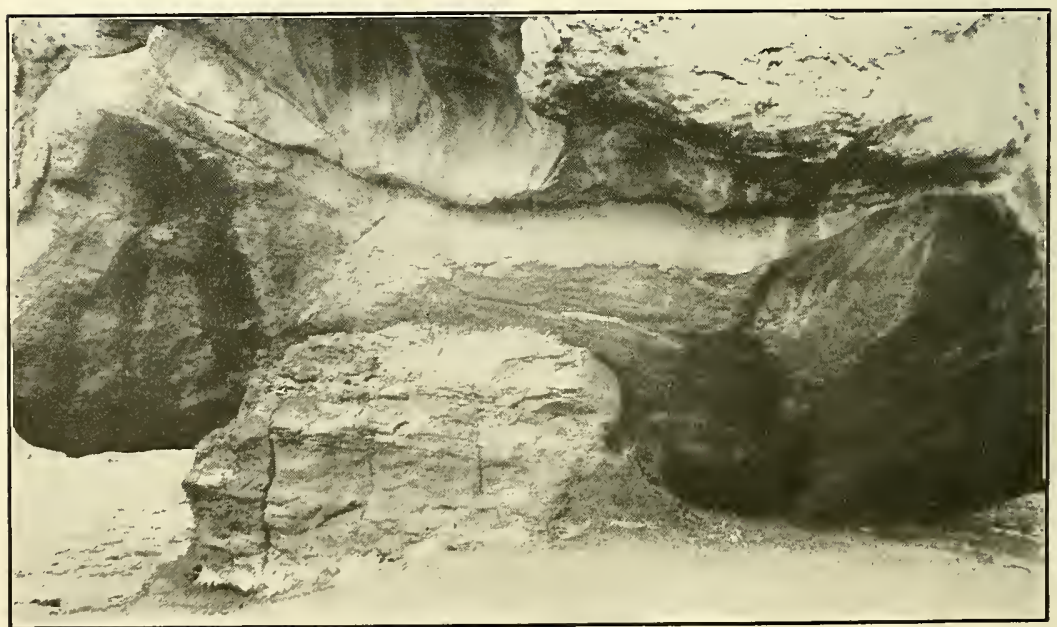

$B$. STAINS ON UNDER SIDE OF BOULDER.

Showing that the film of water formed during rains extends to the top of the pedestal, which is marked by white patches due to the eflorescence of salts. 


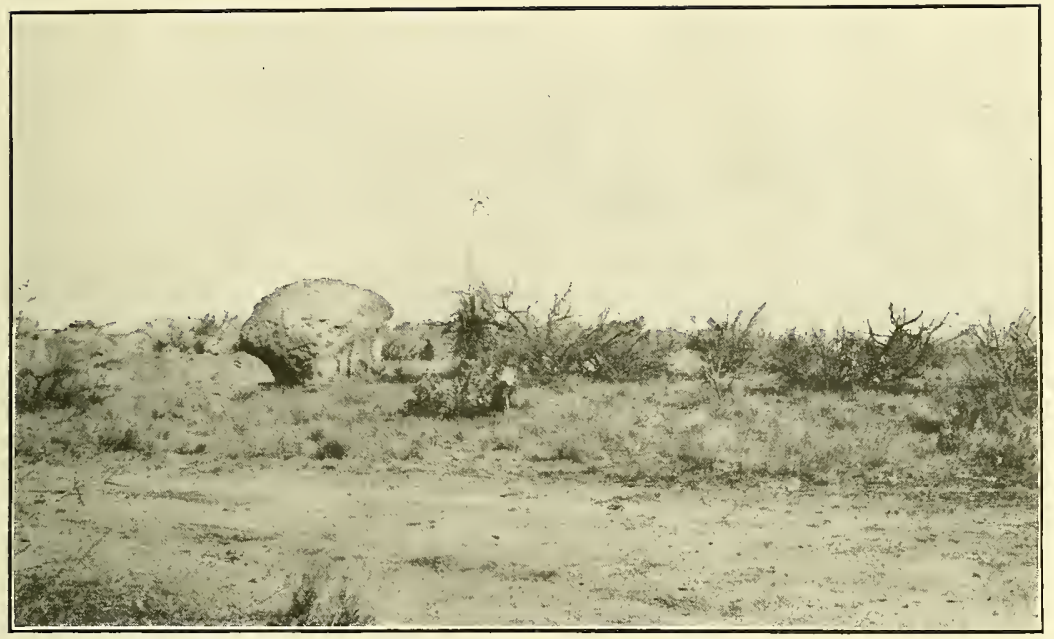

A. PEDESTAL ROCK OF GRANITE.

Two miles northwest of Oracle, Ariz. Note vegetation of catclaw, yucea, cactus, small bushes, and grass.

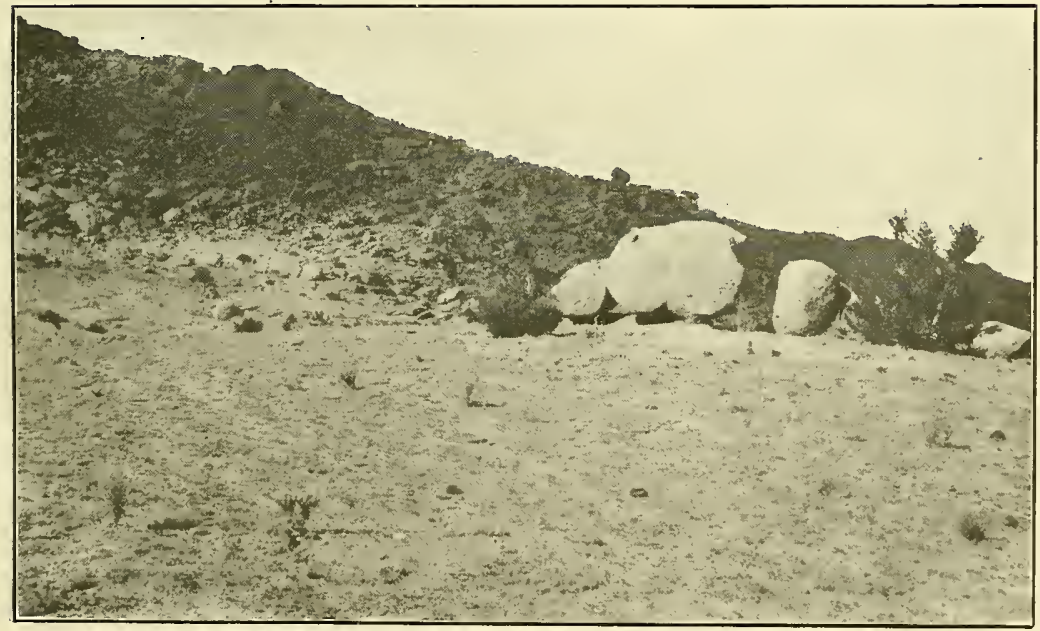

\section{B. PEDESTAL ROCKS AND BOULDERS OF EROSION.}

Tijeras Canyon, Sandia Mountains, N. Mex. Note the rough surfaces of the granite boulders and the inlluence of joint planes on the shape of boulders. The elosely grazed grassy foreground is part of the slope to the old valley at the right. The mountain slope of the background has numerous boulders of erosion and pedestal rocks. 

are not numerous, for the blocks of the pedestal rocks weather slowly, as shown by their smooth brown and incrusted surfaces.

Those blocks which are so placed that the bedding planes are vertical have no such smooth crust. Their surfaces are rough and are bright in color. Pebbles and fragments of the matrix are easily detached with the fingers. The blocks shed numerous durable fragments, which, lying at the bases of the blocks, protect the underlying shale from the drip. Doubtless also the rough surfaces retard the movement of water and more of it penetrates into the rock. Light rains probably cause no drip from such blocks. For these reasons rocks with vertical bedding planes stand on conical hillocks, whose slope is determined by the ability of entirely local rain wash to erode the shale under the protecting film of gravel. That the type of surface characteristic of the Shinarump blocks enables the film of water to extend to the under side of the block for 3 feet before falling probably explains the fact that only large blocks much more than 6 feet in diameter stand on pedestals. The block about 6 feet in diameter shown on the left in Plate II, $B$, has so small a pedestal that its fall to the left seems imminent.

The pedestal, if formed wholly by the action of the drip curtain, should be as large as the annular ring of the drip furrow. However, most of the pedestals are slimmer, like those of the rocks shown in Plates I, $B$, and II, $A$. These pedestals and the pedestals of many other rocks have been eroded more than 3 feet back of the drip curtain. They have almost vertical sides, and there is no talus or slope of loose material between the pedestal and the drip furrow. These features may be explained by the action of the film of water that extends inside the drip curtain. In the rain of July 14, 1921, the film merely moistened the top of the pedestal, but in great storms water may completely cover it. Even a small amount of water is effective in the erosion of the Moenkopi formation, for it is sandy and porous, has well-defined vertical joints, and is impregnated with gypsum and other soluble salts. A small amount of water applied at the top and soaking into the pedestal is sufficient to open the joints and bring to the surface the soluble salts, as shown in Plate IV, $A$ and $B$. The shale not only crumbles and "slacks" at the surface but sloughs off along the vertical joints. The vertical sides of the pedestal may therefore be explained by the work of the film of water due to ordinary storms, but it is not certain that even great rains would produce enough water for the film to cover the entire pedestal and run off at the foot in large enough quantities to carry away the talus. The direct erosive action of wind-driven rain, ${ }^{9}$ the splash from the drip furrow, and the lateral migration of rivulets

${ }^{9}$ Kinahan, G. H., Valleys and their relation to fissures, fractures, and faults, p. 83, London, 1875. Attributes part of erosion of pedestal rocks of Devonshire to wind-driven rain. 
must therefore be called upon for the removal of the talus. It is also possible that wind scour may play a part in the removal of talus, though no tangible evidence of such scour was found.

The foregoing description and analysis seem to indicate that rain and the ordinary processes of weathering are competent to form pedestal rocks, and this conclusion is corroborated by the contrast between the bases of blocks with vertical and those with horizontal bedding planes.

\section{POSSIBLE EFFECTS OF WIND WORK.}

Prior to the observations just described the writer made a journey along the base of the Vermilion Cliffs and noted the number and characteristics of pedestal rocks, although the rocks observed during the rain of July 14 were not visited. No considerable rain had fallen here for more than a year, and hence mechanical processes of erosion and wind abrasion had had full sway for a long period. Neither the pedestals nor the ground beneath them were grooved by wind action, but many pedestals had been used as rubbing posts by cattle, who love "the shadow of a great rock in a weary land," and in this manner a small amount of erosion had been accomplished, but the cow dung, much of it pulverized by trampling, had not been removed by wind action. No wind polish was observed on the blocks of Shinarump conglomerate nor on flakes of hard sandstone from the Moenkopi.

These observations are not in accord with those of Gilbert, ${ }^{10}$ who on visiting this locality in 1871 was much impressed by wind work. $\mathrm{He}$ ascribes a large part of the erosion of the Moenkopi to wind scour and considers that the pedestal rocks are formed by the excavation of the shale around the base of each rock by wind action. Davis, ${ }^{11}$ however, mentions the rocks and says that they are isolated by the recession of the cliffs. He explains, at some length, the recession of the cliffs in terms of water action. It is evident that Davis did not consider wind action effective in molding the surface at the base of the cliffs.

In many places near the pedestal rocks the writer observed evidence of wind action in accumulations of wind-blown sand. Skirting the cliffs at the base of which stand the pedestal rocks and extending down to the Kaibab limestone, which forms the rim of Marble Canyon, is a sloping plain or pediment, ${ }^{12}$ developed largely on the Moenkopi shale and graded to the top of the Kaibab as a local base-level. The major streams, such as Badger and Soap creeks, have, however, intrenched themselves in canyons that extend from Marble Canyon to the base of the cliffs. It is only the small streams and the rills and

10 Op. cit., p. 84, pl. 11.

11 Op. cit., vol. 38 , p. 134, pl. 2.

12 Bryan, Kirk, Erosion and sedimentation in the Papago country, Ariz.: U. S. Geol. Survey Bull. 730, pp. 52 et seq., 1922. 
rivulets that during and after rains flow over this sloping pediment toward the river. Part of the pediment is mantled with wind-blown sand from a few inches to 3 feet deep. Between Badger and Soap creeks and between Soap Creek and Jacobs Pools the sandy areas are extensive. It is noticeable, however, that the sand has accumulated in a more or less continuous blanket at some distance from the Shinarump cliffs, and the pediment at the base of the cliffs is relatively free from sand, showing only windrows of sand a few feet long and 6 inches to a foot wide and little piles of sand near loose rocks, behind bushes, and in the channels of rills. The surface also is generally covered by pebbles mostly loosened from the Shinarump conglomerate and flakes of thin sandstone from the Moenkopi formation. During the long dry period before this journey the wind had been active on the slope, but the work it accomplished had not been large. Only in a few places was the relatively soft ground scarred or grooved, and in no place had the channel of rills been obliterated, though months had elapsed since they carried any water. The windrows and piles of sand had more or less imperfectly filled some of these channels, and to such damming by wind-blown sand some of the lateral migration of streams on pediments and alluvial slopes may be safely attributed. There was a general cover of pebbles and blocks of sandstone, of the type usually called a "desert pavement." The value of such pavements as evidence of wind erosion has been much exaggerated. In favorable places similar pavements can be seen in humid lands, as, for instance, on some of the gravelly terraces near Washington, D. C. The pavement can be produced by flowing water ${ }^{13}$ or by rain wash, which removes the fine and leaves the coarse material. The latter process was observed during the shower of July 14. The existence of a "desert pavement" in such a place is not proof that the wind is active; it may only be proof that wind action has been too feeble to cover with sand or destroy a pavement produced by rain wash during the last rain.

The foregoing review of wind action in this locality shows that it is a comparatively minor force in erosion here, though it is effective in other parts of the Lees Ferry region. ${ }^{14}$ Its principal work has been to accumulate sand in intercanyon areas, where the sand can not with the present absence of stream action be easily removed by streams. The wind has also assisted in the diversion of rivulets on the pediments at the foot of the cliffs.

\section{PEDESTAL ROCKS IN SOUTHERN ARIZONA.}

In a number of localities in the drainage basin of San Pedro River, in southern Arizona, isolated rocks ranging in shape from masses of boulders to pillars and pedestal rocks are common. The pedestal rocks differ from the other rocks only in having overhanging sides.

13 Free, E. E., The movement of soil material by wind: U. S. Dept. Agr. Bur. Soils Bull. 68, p. 32, 1911.

14 Bryan, Kirk, Wind erosion near Lees Ferry, Ariz.: Am. Jour. Sci., 5th ser., vol. 6, pp. 291-307, 1923. 
The origin of the overhang is not wholly clear, but evidence is presented below to show that these pedestal rocks, like the pedestal rocks of the Lees Ferry region, can not be ascribed to wind erosion. These rocks occur northwest of Tombstone; at Stronghold Canyon, on the west side of the Dragoon Mountains; in Texas Canyon, in the south end of the Little Dragoon Mountains; north and west of Oracle; and at various places in the Tortilla Mountains north of Oracle. In all these localities the surface is underlain by coarse-grained granite with characteristic widely spaced joints.

The climate is generally mild, though freezing weather is common in winter. There is a double rainy season: the winter rains are gentle and are due to general storms; the summer rains are violent local showers. The rainfall is sufficient to maintain a thin cover of perennial grass on most of the surface at all the localities. The Stronghold Canyon, Texas Canyon, and Oracle localities lie at the dry timber line, which in this region is the contact zone of the desert scrub, mesquite, catclaw, etc., and the liveoak and manzanita woodlands. The localities near Tombstone and in the Tortilla Mountains lie in the zone of desert scrub.

The available weather records are summarized below:

Precipitation at three stations in San Pedro Valley, Ariz.

[As compiled to 1913 by the United States Weather Bureau.]

\begin{tabular}{|c|c|c|c|c|c|c|c|c|}
\hline Station. & $\begin{array}{c}\text { Altitude } \\
\text { (feet). }\end{array}$ & $\begin{array}{l}\text { Number } \\
\text { of years. }\end{array}$ & Jan. & Feb. & Mar. & Apr. & May. & June. \\
\hline 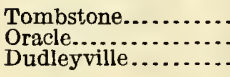 & $\begin{array}{l}4,550 \\
4,500 \\
2,200\end{array}$ & $\begin{array}{l}17 \\
22 \\
25\end{array}$ & $\begin{array}{l}0.77 \\
2.01 \\
1.31\end{array}$ & $\begin{array}{l}1.30 \\
1.95 \\
1.55\end{array}$ & $\begin{array}{l}0.86 \\
1.57 \\
1.03\end{array}$ & $\begin{array}{r}0.33 \\
.59 \\
.52\end{array}$ & $\begin{array}{l}0.24 \\
.36 \\
.36\end{array}$ & $\begin{array}{r}0.41 \\
.37 \\
.26\end{array}$ \\
\hline Station. & & July. & Aug. & Sept. & Oct. & Nov. & Dec. & $\begin{array}{c}\text { Mean } \\
\text { annual. }\end{array}$ \\
\hline $\begin{array}{l}\text { Tombstone } \ldots \ldots \ldots \\
\text { Oracle .............. } \\
\text { Dudleyville....... }\end{array}$ & & $\begin{array}{l}3.31 \\
2.47 \\
2.13\end{array}$ & $\begin{array}{l}3.61 \\
3: 64 \\
2.70\end{array}$ & $\begin{array}{l}1.64 \\
1.33 \\
1.23\end{array}$ & $\begin{array}{r}0.52 \\
.79 \\
.92\end{array}$ & $\begin{array}{r}0.80 \\
1.82 \\
.96\end{array}$ & $\begin{array}{l}0.75 \\
1.73 \\
1.32\end{array}$ & $\begin{array}{l}14.54 \\
18.63 \\
14.29\end{array}$ \\
\hline
\end{tabular}

Under the prevalent climate the granite of these localities breaks up largely through the mechanical processes of weathering and tends to produce castellated forms. There is, however, sufficient moisture to make chemical action more pronounced than in the more arid portions of Arizona. ${ }^{15}$ The pedestal rocks and similar isolated forms occur in places where pediments have been dissected and new pediments are in process of formation, at a lower level, not more than 150 feet below the old surface.

With variations in detail the origin of the pedestal rocks in these localities is similar, and the example shown in Plate $\mathrm{V}, A$, will serve

${ }^{15}$ Bryan, Kirk, Erosion and sedimentation in the Papago country, Ariz.: U. S. Geol. Survey Bull. 730, pp. 37-52, 1922. 
as a model for all. This rock stands, with numerous similar monoliths, on the pediment northwest of Oracle, a plain of erosion and transportation formed by streams that flow from the north end of the Santa Catalina Mountains. At this place the direction of flow is northwestward to Big Wash, whence, in time of flood, water finds its way south and then west into Santa Cruz River. The pediment has been formed by the dissection of an older pediment of similar form and somewhat greater extent, formed by the same streams when they flowed at a level about 150 feet higher. In dissecting this older pediment the streams first cut narrow, steep-walled canyons, which grew headward by the erosion of falls. Later these canyons widened, tributary canyons were cut, and mesas and hills were isolated in the interstream areas. In this locality most of these residual hills have been reduced to masses of boulders or to monoliths.

That masses of boulders and monoliths should be left by erosion in places where the joints of the granite are widely spaced is not surprising, but the not uncommon mushroom shape seems to be due to special causes.

The soil on this pediment is a gravelly loam, composed of débris of the granite with many grains of feldspar, in part a residual soil, but mostly transported material brought from higher portions of the pediment in the infrequent floods. The major streams are slightly incised and in neighboring localities have begun the formation of a new pediment. Here, however, the streams wander more or less at will over the plain. Inspection of artificial excavations near by shows that in places the soil is only 2 to 3 inches thick over the granite, and residual soil is almost indistinguishable from transported soil. Both types of soil are dark and have a visible content of vegetable matter. These characteristics are evidence of the retention of moisture throughout a large part of the year, and in consequence there is a good growth of bushy plants and of perennial grass. In the spring the ground is covered with alfileria.

The character of the soil has an effect on two processes, chemical weathering of rocks and wind work. The granite underlying flat surfaces, as seen in numerous excavations near by, is decomposed to depths of 10 to 20 feet. The ferromagnesian minerals are almost wholly destroyed, and the feldspars have become opaque and kaolinized. The soil moisture and the ground water circulating in the cracks of the granite are apparently effective in decomposing the rock. Chemical weathering is much less pronounced in the residual hills and masses of boulders, but these places have little soil, and because of their elevation the ground water drains away from them. The projecting rocks are therefore eroded largely by mechanical weathering-that is, granular disintegration and exfoliation. The dark humus-bearing soil is compact and not easily 
disturbed by wind; moreover, the numerous shrubs and the partial sod formed by clumps of perennial grass inhibit wind scour. In March, the month of most wind, the alfileria generally forms a blanket over the surface. The spring of 1921 was unusually dry, and the alfileria merely started to grow and then died. Yet during several days of high wind the writer saw no dust rise or sand move on the pediment north of Oracle, though great clouds of dust were raised from the sandy beds of Big Wash and San Pedro River.

The carving of a monolith into a form with overhanging sides, as in the example illustrated in Plate $\mathrm{V}, A$, must be due to special causes that can not be closely defined, yet wind work, as shown in the preceding paragraph, is definitely eliminated. The rock doubtless originates as a block bounded by joint planes along which weathering proceeds, and it remains as a unit after the surrounding joint blocks have been removed. The formation of the concave sides from joint planes that were originally vertical or slightly inclined is related to the formation of the smooth and iron-stained crust that caps the rock. This crust protects the upper part of the rock from granular disintegration under changes of temperature, a process that seems to have played a large part in the formation of the light-colored surfaces of the sides with their projecting mineral grains. It seems likely also that the surrounding moisture-retentive and humus-bearing soil promotes chemical action at the base of the rock and tends to undermine the walls. The débris resulting from this combined mechanical and chemical erosion is periodically removed by drip from the rock during rains and by the ephemeral streams of the surrounding pediment.

\section{ROCKS OF THE PEDESTAL TYPE IN CENTRAL NEW MEXICO.}

Near the mouth of Tijeras Canyon, in the Sandia Mountains, about 10 miles east of Albuquerque, N. Mex., there are numerous isolated masses of boulders, rocking stones, pillars, and monoliths. Some of them resemble the pedestal rocks described above, though none of them are particularly striking in appearance.

The climate is arid, with a relatively strong concentration of rain in the summer. There are winter frosts, but not much snow. No rainfall records for stations near by are available. The altitude is about 6,000 feet, and in central New Mexico localities at that altitude usually have an annual precipitation of 10 to 12 inches.

Tijeras Canyon consists of an older valley trenched by a narrower steep-walled younger valley which is partly filled with alluvium. ${ }^{16}$ Near the mouth of the canyon the pediment that skirts the western.

${ }_{10}$ Bryan, Kirk, Geology of the vicinity of Albuquerque, N. Mex.: New Mexico Univ. Bull. 51, Geol. ser., vol. 3, No. 1, pp. 7-8, fig. 2, 1909. 
front of the Sandia Mountains is continuous with a wide bench that forms a part of the older valley. ${ }^{17}$ Boulders mark this old erosion surface $(\mathrm{Pl} . \mathrm{V}, B)$. Some are mere clusters of rocks; others are nearly of the perfect pedestal form. They are produced by granular disintegration and exfoliation from the underlying and locally coarsegrained biotite granite. That wind scour is not an agent in their formation is established by the lack of wind-blown material and the presence of perennial grass, which is plainly visible in the photograph, although it has been closely cropped by goats belonging to the inhabitants of the near-by village of Carnuel. The local coarse soil composed of granite débris has particles too large to be moved by the wind and is also held in place by grass roots. The surfaces of the rocks show no polish but, on the contrary, have a rough texture due to the projecting of individual mineral grains, similar to the texture of the surfaces of the sides of the rocks at Oracle, Ariz. This surface is a typical result of the mechanical disintegration of granular rocks under changes of temperature, and to this process together with exfoliation is due the form of these rocks.

\section{CONCLUSION.}

The pedestal rocks described in this paper are of various types and cover a wide range of climatic conditions. Not all types of pedestal rocks are included, and it is possible that by chance those described are unusual. The examples cited, however, are to be attributed to the work of rain, of mechanical disruption, and of chemical weathering, and none of them would serve in any sense as proof of wind work. It would seem, therefore, that caution should be exercised in using the presence of pedestal rocks as a criterion of wind erosion.

17 Ellis, R. W., Geology of the Sandia Mountains: New Mexico Univ. Bull. 108, Geol. ser., vol. 3, No.4, p. 14, pl. 1,1922 . In this paper part of the pediment is mapped as "old base-level." 


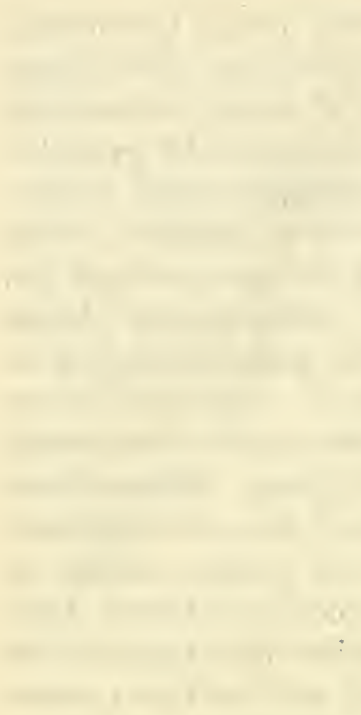




